\title{
What Does It Take to Make the Proper Restaurant Design?
}

\author{
Samuel PD Anantadjaya, Timotius A. Rachmat \\ Faculty of Business \& Social Sciences \\ International University Liaison Indonesia \\ Tangerang, Indonesia \\ ethan.eryn@gmail.com
}

\author{
Aditya Nova Putra, Yoanita Alexandra, Livia Christie \\ PT. Tutup Panci Indonesia, BSD City \\ Tangerang, Indonesia \\ inawangwulan@gmail.com
}

\begin{abstract}
From the field of study on marketing, consumer behavior is regarded as an important tool for an organization; it can help an organization develop their products or brands in a right path (Setiawan, 2011; Schiffman \& Kanuk, 2009). It also helps an organization keep their customer satisfied by knowing more their needs and wants (Lantos, 2011). In particular, consumer characteristics, which mainly encompasses around culture, social and personal, may play an integral role in influencing the restaurant designs. From the notion on Organizational Citizenship Behavior (OCB), it is regarded to have influenced psychology and supervision in organizations. Such sets of behaviors are essential to assist organizations sustainability (Mohammad, Habib, \& Alias, 2011), and assisting managers in evaluating the working environment, motivation, and satisfaction of employees (Davoudi, 2012). The presence of good citizens in organizations may likely push toward a higher level of organizational effectiveness and widening the chances on growth when employees go beyond the specified tasks and responsibilities. The combination of these variables may push for the properness of restaurant design. With the increasing demands, restaurants are challenged with increasing level of competition. Restaurant design may well be considered as one of the drivers in luring for a higher customer loyalty. Based on a geographically-clustered sampling method, this study focuses on individuals, who have eaten in a casual dining restaurant, at least once. It is interesting to examine the influential degrees of the variables and indicators used in this study in restaurants. Findings show that variables and indicators used have proven to have the influential contributions to the level of customer loyalty.
\end{abstract} loyalty

Keywords- consumer behavior, OCB, restaurant design,

\section{INTRODUCTION}

Customer attraction, loyalty, and relationship are matters a lot in business world besides price. Companies nowadays are very conscious about their customer's satisfaction (Malik, et al., 2013). Consumers in today's world seem to be more aware of the products they buy, and at the same time, products are also developing. By understanding consumer behavior, an organization can develop their products or brands in the right

\author{
Irma M Nawangwulan \\ School of Management Studies \\ Universitas Pembangunan Jaya \\ Tangerang Selatan, Indonesia \\ temmyr@gmail.com
}

\author{
Kevin Juliawan \\ PT. Kang Guru Beruang, BSD City \\ Tangerang Selatan, Indonesia \\ aditya.nova01@gmail.com
}

way. It also helps the marketers to know more about consumer's needs and wants, to keep the customer satisfied and to keep them on track with the marketing concept (Lantos, 2011).Studying customers provides information for developing new products, product features, prices, channels, messages, and other marketing-mix elements (Kotler \& Keller, 2012). Every customer has their own, different characteristics which will affect their mindset and perspective about a restaurant and the products they have bought.

Based on a research article by Li Mei Hung (2012), Taiwanese select a coffee shop based on the staff service quality and a pleasant dining experience. Professional knowledge on coffee is also crucial. The dining experience emphasizes on a diverse range of meals and coffee variations, focusing on the quality of the meals, quality of tableware, portion sizes of meals and/or beverages, and how crowded the coffee shops are. In terms of staff, emphasis is on the staff appearance and etiquette, extensive professional knowledge, and the ability to responsiveness to customers' inquiries. Attention to store location, price level, discount frequency, and the café's reputation are also considered important.

In today's era of globalization, human resource has become the main driver in organizations to reach the organization's targets (Narayan, 2010). It has become essential for organizations to handle and organize the personnel properly. The factors like capability, identity, encouragement, and values have been considered as intangible assets to direct organizational results (Saepung, Sukirno, \& Siengthai, 2011). Differences in employees' motivation and satisfaction (Arif \& Chohan, 2012) are also extending crucial contributions. If satisfaction is related to how well employees perceive the jobs/tasks ${ }^{1}$ (Aziri, 2011), motivation is more into the willingness to put-in more into the jobs/tasks (Aworemi, Abdul-Azeez, \& Durowoju, 2011). Hence, both factors are

${ }^{1}$ Whether the employees perceive his/her jobs/tasks happy/unhappy, like or dislike (Aziri, 2011). This means that the happier the employees, there is a higher chance that those employees have higher willingness to do extra works (Sageer, Rafat, \& Agarwal, 2012; Anantadjaya, 2011) 
important for organizations. Organizational Citizenship Behavior (OCB) influences both psychology and supervision in organizations. Considering and creating this behavior among members of organizations are essential (Mohammad, Habib, \& Alias, 2011; Öztürk, 2010; Ünal, 2013) to assist managers in evaluating the working environment, motivation, and satisfaction of their employees (Davoudi, 2012; Miao, 2011). This behavior supports organizations to go beyond duties and responsibilities.

With the rising trends on restaurants, bars, traditional market and cafes in the city of Jakarta and its surrounding proximities, the tight competition among players are obvious. The numbers of casual dining establishments with new concepts of design are steadily increasing. Obviously, it takes a lot more than food to create a good dining experience. Restaurant environment must target the most meaningful experience to all restaurant patronages. From ambient, social and design factors are all vital contributing elements to the positive dining experience to visitors (Ariffin, Bibon, \& Saadiah, 2011; Putra, Saroso, \& Anantadjaya, 2015). People's attitudes, behavior and well-being are influenced by the aesthetic quality of the environment (Ariffin, Bibon, \& Saadiah, 2011). According to the study in USA by the University of Minnesota (Robson, 2002), as much as $95 \%$ of purchase decisions are likely based on emotional responses rather than rational/logical considerations. Since new restaurants tend to offer unique concepts, this increases difficulties in grabbing the level of loyalty.

The National Restaurant Association (NRA) reported that restaurants derive a large portion of profits from loyal customers (National Restaurant Association, 2013a; 2013b). At the average check of US\$25, for instance, those regular customers contribute about $60 \%$ to the restaurant's revenues. Approximately $27 \%$ of first-timers to the restaurants' loyalty programs have returned within the short period, and $14 \%$ of those first-timers to the loyalty programs have visited twice in 3 months. However, for those first-timers who decided not to join the loyalty programs, only about $12 \%$ of them returned only once, and a mere $3 \%$ of those first-timers who did not join the loyalty programs have returned at least twice (Holscher, 2013).

\section{A. Consumer Behavior}

It is often interesting to examine individual mental process in making purchase decisions. Though, on average, the mental processes should be similar, nonetheless, the actual purchase may be vastly different across individuals (Schiffman \& Kanuk, 2009). These differences reflect the variations in consumer personal psychology and characteristics, and also the attitudes of consumer in accepting marketing and other stimulants (Kotler \& Keller, 2012). This study only focuses on consumer characteristics of many other consumer behavior elements/factors in trying to approximate the likelihood of purchase decisions (Setiawan, 2011). The proxies used for the consumer characteristics in this study are; cultural ${ }^{2}$ (Kotler \& Armstrong, 2014; Kotler \& Keller, 2012; Solomon, 2013),

2 This includes culture, sub-culture and social class (Kotler \& Armstrong, 2014; Kotler \& Keller, 2012) social $^{3}$ (Kotler \& Keller, 2012; Solomon, 2013; Mullins \& Walker, 2010) and personal ${ }^{4}$ (Parsa, Gregory, Self, \& Dutta, 2012; Kotler \& Armstrong, 2014)

In general, culture influences individual wants and behaviors (Kotler \& Armstrong, 2014). From defining the "personality" of the surrounding society, culture will eventually shape individual identities and values (Solomon, 2013). As a part of culture, nationalities, religions, ethnic groups, and geographical regions, are making-up the subculture elements to provide more identifications of certain societies. The existence of the sub-culture persuades the emergence of social stratifications, which is known as the social class $^{5}$ (Kotler \& Armstrong, 2014; Kotler \& Keller, 2012; Solomon, 2013). Prior studies have indicated that culture determines the attachment of individuals toward certain activities, including particular products and/or services (Solomon, 2013). Reference groups, family, social roles and status also determine individual behaviors (Kotler \& Keller, 2012). People in similar income level usually belong in the same social class. This denotes similar tastes, preferences, interests, and those people tend to socialize together (Solomon, 2013; Mullins \& Walker, 2010). As stated, personal characteristics also influence buyer's purchase decisions (Parsa, Gregory, Self, \& Dutta, 2012). Individual consumptions usually mirror the age, stages in the family life-cycle, occupation and economic condition (Kotler \& Armstrong, 2014). Undoubtedly, since restaurants have become the socialization places and hang-out spots, in addition to a mere obtaining regular meals, the combinations of these factors are certainly expected to alter the acceptable design in restaurants.

Hence, it can be hypothesized that;

$\begin{array}{ll}\mathrm{H}_{1} \quad \text { : } & \text { Consumer characteristics positively } \\ \text { influences restaurant design }\end{array}$

\section{B. Job Satisfaction and $O C B$}

Job satisfaction is an essential factor for organizations. It can certainly be used as a parameter in measuring employee's effectiveness (Aziri, 2011) since the higher level of job satisfaction will likely bring more positive attitude to employees (Robbins \& Judge, 2013; Arokiasamy, Tat, \& Abdullah, 2013; Hussin, 2011). If the employees were happy (or satisfied), those employees will likely to continue working in the organizations (Arif \& Chohan, 2012). This means costsavings to the organizations, in terms of lower employee turnover (Suma \& Lesha, 2013), lower costs and higher productivity (Suma \& Lesha, 2013). The study by Aziri (2011) stated that there are related factors to the employee's job satisfaction, such as; the work itself (Management Study Guide, 2013), pay, improvement opportunities, the company supervisors, working environment, and the teamwork (Craven

\footnotetext{
3 This includes reference groups, family, and social roles and statuses (Kotler \& Armstrong, 2014; Kotler \& Keller, 2012)

4 This includes buyer's age and stage in life cycle, occupation, economic circumstances, lifestyle, and personality and self-concept (Kotler \& Armstrong, 2014; Kotler \& Keller, 2012)

5 Social class is divided into; upper, upper-middle, middle, working, and lower (Mullins \& Walker, 2010).
} 
\& Piercy, 2009; Kumari, 2011; Ebert \& Griffin, 2011; Baylor, 2010), in addition to the notions on intrinsic ${ }^{6}$ and extrinsic ${ }^{7}$ job satisfaction (Ebert \& Griffin, 2011; Nadim, Chaudhry, Kalyar, \& Riaz, 2012; Baylor, 2010). The study on job satisfaction is regarded important since it evaluates various reasons and factors which influence the fluctuations on employee's job satisfaction (Sageer, Rafat, \& Agarwal, 2012).

The above mentioned elements of job satisfaction denote the people, and the structure of organizations (Robbins \& Judge, 2013). Equipped with those elements, organizational potentials increase toward the advancement in the future (Tanaka, 2013). OCB $^{8}$ refers to the outcomes of individual behaviors beyond what are originally expected by organizations (Robbins \& Judge, 2013; Vaijayanthi, Shreenivasan, \& Roy, 2014). Williams and Anderson (Mohammad, Habib, \& Alias, 2011) also determined the types of OCB based on whom the behaviors are aimed at; Organization Citizenship Behavior towards an Individual (OCBI) and Organization Citizenship Behavior towards the Organization (OCBO). Considering the 5 dimensions of OCB, on one side, altruism and courtesy contribute to OCBI (Newland, 2012), where employees help other individuals or are concerned with others. On the other side, conscientiousness, civic virtue, and sportsmanship contribute to OCBO, where employees behaviors are more directed to the benefits of the organization. As mentioned, researchers around the world have studied about OCB and its likelihood antecedents until now. Job satisfaction is considered as the most substantial element on job attitudes. OCB is the subsequent result of high degree of job satisfaction (Davoudi, 2012). Satisfied employees have the tendency to show OCB. An employee who may have a good relationship with his/her colleagues may have the tendency to show altruistic behaviors in terms of extending assistance in accomplishing tasks (Robbins \& Judge, 2013).

Designs of any establishments can take-on various forms. Restaurant designs, for example, range from fast-food type of design to an elegant fine-dining at the rotating roof-tops. Interiors of the restaurants also range from the casual style to particular theme-based interiors. With the trends on competing interiors, categories begin to emerge on the importance of restaurant designs (Simpson, 2003). If such competing designs were perceived from $\mathrm{OCB}$, unique designs may potentially emerge from the combinations of employees' job satisfaction,

\footnotetext{
${ }^{6}$ Factors on intrinsic job satisfaction (Baylor, 2010) include; achievement, recognition (Bradler, Dur, Neckermann, \& Non, 2016), the work itself (Management Study Guide, 2013), responsibility (Kumari, 2011), advancement \& growth (Sageer, Rafat, \& Agarwal, 2012).

${ }^{7}$ Factors on extrinsic job satisfaction (Baylor, 2010), or also known as the hygiene factor in the two-factor motivational theory (Management Study Guide, 2013), include; supervision, working condition (Leblebici, 2012), interpersonal relationship, company policy, salary (Sageer, Rafat, \& Agarwal, 2012), job security (Sageer, Rafat, \& Agarwal, 2012), and status.

${ }^{8}$ Research on OCB was initially started by Dennis Organ in 1980s (Öztürk, 2010). Until now, the research on OCB and its antecedents, such as leadership behavior, organizational commitment, organizational culture, job satisfaction, and many others have been done by many researchers (Davoudi, 2012). Dimensions on OCB include; altruism, concientiousness, civic virtue, courtesy, and sportmanship (Öztürk, 2010; Ünal, 2013; Islam, Ahmad, Ahmed, \& Mohammad, 2012).
}

altruism, courtesy, conscientiousness, civic virtue, and sportsmanship. If such competing designs were perceived from consumer characteristics, on the other hand, distinctive designs may potentially emerge from the combinations of culture, social and personal factors.

Hence, it can be hypothesized that;

$\mathrm{H}_{2} \quad$ : Job satisfaction positively influences OCB

\section{C. $O C B$ \& Design}

There are countless of elements to take into consideration in dealing with interior design (Simpson, 2003). It appears to be not enough elements to even come close in achieving the best results. Nevertheless, this study focuses only on a handful of elements in relation to designs, as follows (Pavesic, 2005);

a. According to Singh (2006), the choices of colors stimulate individual senses. Colors have the power to recall memories in individual minds. Color is important in creating the positive associations. From the marketing field, color holds the vital role in relaying messages to people (Thenni, 2013).

b. Shapes have the potentials in communicating different messages and meanings to the society. Rectangular, can be easily opened, and made of organic materials transmit different messages and meaning in comparison to round, and made-of non-organic materials. Any changes in shapes may likely alter individual perceptions about the overall messages and meaning (Bradley, 2010).

c. The approximate largeness or smallness of designs also dictates the space and comfort. The size can also create other elements as large or small depending on the available space in-between (Thenni, 2013).

d. Scent is crucial in extending the intended messages. Unmatched scents to the product/services offered may lead to negative perception (Ertzberger, 2009). Other surrounding elements, including the overall design, music, layout, and decoration have the tendency to alter emotions and hopefully increasing willingness to stay longer in the premises. This boost shopping experience (Ertzberger, 2009).

e. Room temperature should also be considered for personal comfort (Thenni, 2013).

f. Ornament is also necessary to not only offer the functions, but also to display social status (Yu, 2009). Intricate details may be used to fascinate people and lure them to stay longer in the premises to admire the craftsmanship (Yu, 2009).

g. Sound is essential to boost emotions and relaxation (Malekshahi, 2013; Yu, 2009). Acoustic materials can be use as sound absorbance ( $\mathrm{Yu}, 2009)$. In much of the same ways is about lighting to create pleasant and desirable environment (Malekshahi, 2013).

h. Materials and texture used for the floors, walls, tables, chairs, and counter-tops should also be considered to be align to the general concepts of the designs (Malekshahi, 2013) 
i. Restaurant physical menu should also be considered as a part of the overall restaurant design (Baiomy, Jones, Elias, \& Dinana, 2013). Good menu is advantageous to lure people in making selections (Kotschevar \& Withrow, 2008; Ozdemir \& Caliskan, 2013; Buchanan, 2011; Bowen \& Morris, 1995). This enhances dining experience (Marković, Raspor, \& Šegarić, 2010). Menu appearance should incorporate components of color, typeface, layout, paper, illustration and graphic design (Putra, Saroso, \& Anantadjaya, 2015; Shock, Bowen, \& Stefaneli, 2004; Singh, 2006). Each of the components should complement the others (Scanlon, 1985).

The combination of those design elements can only be unique when employees are all working together beyond their formal job descriptions and attempting to really extract the capabilities. Hence, it can be hypothesized that;

\section{$\mathrm{H}_{3} \quad$ : OCB positively influences restaurant design}

\section{Customer Loyalty}

Customer loyalty can be proxied by behavioral and attitudinal (Eliwa, 2006). The behavior dimension is about customer's behaviors on repeat dining in a specific restaurant over time (Eliwa, 2006). Attitudinal dimension refers to customer's intention to repurchase and recommend or do a word of mouth (Eliwa, 2006). Loyalty includes repurchasing behaviors and preferences toward certain products and services (Alsaqre, 2011). From another study, customer loyalty can also be proxied by environmental attribute, managerial attribute and social attributes (Alsaqre, 2011). From the discussion above, it is certainly expected that the restaurant design may likely influence the level of loyalty.

Hence, it can be hypothesized that

$\mathrm{H}_{4}$ : The appropriate restaurant design positively influences customer loyalty

\section{E. Research Model}

With the above mentioned literature, the relationships among potential variables and indicators can be illustrated in the following research model on figure 1.

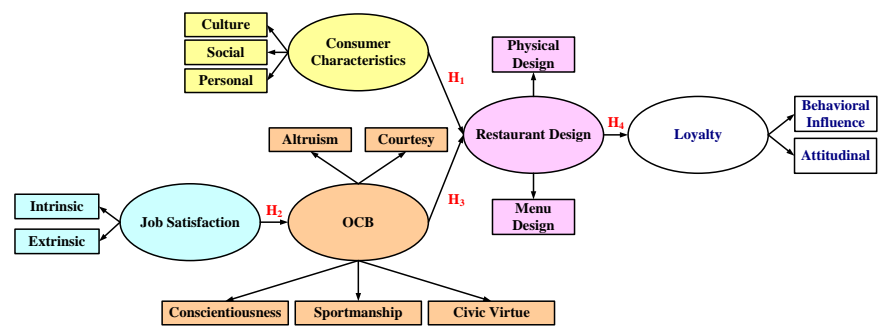

Fig. 1. Research Model

\section{METHOD}

This study relies on the geographically-cluster sampling method to separate countless of restaurants within the proximity of the city of Jakarta and its surrounding areas, mainly Depok, Tangerang and Bekasi. Since questionnaires were distributed via online social media, such as, Facebook,
Instagram, Path, and emails to acquaintances who reside in those targeted locations, personal interactions and/or interviews were not conducted. The following table shows that assuming that only $50 \%$ of the targeted population meets the criteria while maintaining 10\% sampling error, and $99 \%$ confidence, the minimum numbers of sample should be 166 respondents.

TABLE I. SAMPLE SIZE DETERMINATION

\begin{tabular}{ll}
\hline Estimate of True Proportion & 0.5 \\
Sampling Error & 0.1 \\
Confidence Level & $99 \%$ \\
Z Value & -2.5758 \\
Calculated Sample Size & 165.8724 \\
Sample Size Needed & 166 \\
\hline
\end{tabular}

As previously mentioned, the variables and indicators used in this study are; (1) consumer characteristics are approximated by culture, social and personal, (2) job satisfaction is approximated by intrinsic and extrinsic factors, (3) OCB is peroxide by altruism, courtesy, conscientiousness, civic virtue and sportsmanship, (4) restaurant designs are proxied by physical and menu design, and (5) customer loyalty is proxied by behavioral and attitudinal influence.

The relational analysis in this study follows the structural equation modeling (SEM) to examine the simultaneous occurrence of all pre-determined variables and indicators (IBM SPSS Amos, 2016; Arbuckle, 2011; Ghozali, 2004; Santoso, 2009). It is expected that the variables and indicators provide insights on the degrees of influence. Such the degrees of influence may become handy in managerial improvements and decision-making.

\section{RESULT}

\section{A. Respondent Characteristic}

The preliminary frequency-based data analysis reveals the following information on the respondents' characteristics; approximately $52 \%$ of respondents are female, $73 \%$ of respondents are older than 35 years old, $78 \%$ of respondents are married, $65 \%$ of respondents' monthly expenses are more than Rp. 10 million, only $17 \%$ of respondents are students, $15 \%$ of respondents' blood type are $\mathrm{AB}, 94 \%$ of respondents have visited restaurants at least 10 times per week, about $69 \%$ of respondents have spent at least Rp 100,000 per visit in a particular, $9 \%$ of respondents have visited coffee shops at least 5 times a week, $33 \%$ of respondents have visited restaurants due to the overall restaurant design.

The following table shows the sampling method used and distributions of respondents across locations in Jakarta, Tangerang, Depok and Bekasi. Though the response rate of $74 \%$ (or 183 responses) is a bit lower than originally expected, it is considered acceptable. 
TABLE II. SAMPLING METHOD \& PORTION OF RESPONDENT

\begin{tabular}{llllll}
\hline Geography & Target & $\begin{array}{l}\text { Responses } \\
\text { Received }\end{array}$ & $\begin{array}{l}\text { Incomplete } \\
\text { Responses }\end{array}$ & $\begin{array}{l}\text { Completed } \\
\text { Responses }\end{array}$ & $\begin{array}{l}\text { Response } \\
\text { Rate }\end{array}$ \\
\hline Jakarta & 75 & 81 & 19 & 62 & $76.54 \%$ \\
Tangerang & 75 & 57 & 22 & 35 & $61.40 \%$ \\
Bekasi & 75 & 56 & 9 & 47 & $83.93 \%$ \\
Depok & 75 & 52 & 13 & 39 & $75.00 \%$ \\
\hline Total & $\mathbf{3 0 0}$ & $\mathbf{2 4 6}$ & $\mathbf{6 3}$ & $\mathbf{1 8 3}$ & \\
\hline
\end{tabular}

Due to the difficulties in reaching the proportionate distribution across locations, the completed responses are used. Since it is necessary to examine the level of validity and reliability of the available data, the pre-test and post-test were conducted. The pre-test was run with only 55 data from all locations, and the post-test was run with all the completed responses of 183 . Since the available data has been considered reliable $(73.1 \%$ for the pre-test and $77.3 \%$ for the post-test) and valid $(68.5 \%$ for the pre-test and $70.5 \%$ for the post-test) (Santoso, 2009; Sarwono, 2012; Arbuckle, 2011), a normality test should be performed to ensure the fitness of data into the normal distribution as a way to note the potential biases and outliers $^{9}$ (Ghozali, 2004; 2011). The following table shows the results on reliability and validity of the data.

For the data to be normally distributed, the multivariate critical ratio should be between -2.58 and +2.58 (Ghozali, 2004; 2011; Santoso, 2009; Sarwono, 2012; Schumacker \& Lomax, 2004; Arbuckle, 2011). From the following table, it shows that the original data was not considered normal. There were outliers. Once the outliers were excluded, the remaining 171 data were considered normal at the multivariate critical value of 0.482 .

\section{B. Data Analysis}

Relying on the maximum likelihood analysis of SEM, the following results were obtained at Tabel 3 . With the above measurements, the structural equation can be shown in fig. 2 .

From the figure 2, structural estimates, the following analysis can be elaborated;

Job satisfaction positively influences the formation of OCB as much as $81 \%$. The intrinsic and extrinsic factors on job satisfaction have the explanatory power of $86 \%$ and $78 \%$ respectively toward the formation of job satisfaction. This means that both intrinsic and extrinsic factors are relatively equally influential for the overall job satisfaction of employees (Arif \& Chohan, 2012; Arokiasamy, Tat, \& Abdullah, 2013; Aworemi, Abdul-Azeez, \& Durowoju, 2011; Aziri, 2011). Hence, managers should consider these factors in ensuring higher level of job satisfaction. These findings are enriching what the previous studies have empirically proven (Arif \&

${ }^{9}$ Outlier data is the data that have probability value (p1 or $\mathrm{p} 2$ ) smaller than 0.05 (Ghozali, 2004; 2011; Santoso, 2009; Sarwono, 2012; Schumacker \& Lomax, 2004; Arbuckle, 2011).
Chohan, 2012; Arokiasamy, Tat, \& Abdullah, 2013; Aziri, 2011; Baylor, 2010).

TABLE III. CRITERIA OF GOODNESS OF FIT

\begin{tabular}{|c|c|c|c|c|}
\hline Criteria & $\begin{array}{l}\text { According to } \\
\text { Schumaker \& } \\
\text { Lomax (2004), } \\
\text { Wijaya (2009) }\end{array}$ & $\begin{array}{l}\text { According to } \\
\text { Ghozali } \\
(2004), \\
\text { Santoso } \\
(2009)\end{array}$ & $\begin{array}{l}\text { Model } \\
\text { Value }\end{array}$ & $\begin{array}{l}\text { Goodness } \\
\text { of Fit }\end{array}$ \\
\hline $\begin{array}{l}\text { RMSEA } \\
\text { (root mean } \\
\text { square error of } \\
\text { approximation) }\end{array}$ & $\begin{array}{l}\text { RMSEA } \leq 0.08 \\
=\text { better }\end{array}$ & $\begin{array}{l}\text { RMSEA } \leq 5 \\
=\text { better }\end{array}$ & 0.395 & Acceptable \\
\hline $\begin{array}{l}\text { GFI } \\
\text { (goodness of } \\
\text { fit index) }\end{array}$ & $\begin{array}{l}\text { GFI value closer } \\
\text { to } 1=\text { better }\end{array}$ & $\begin{array}{l}\text { GFI value } \\
\text { closer to } 1= \\
\text { better }\end{array}$ & 0.716 & Acceptable \\
\hline $\begin{array}{l}\text { AGFI } \\
\text { (adjusted } \\
\text { goodness of fit } \\
\text { index) }\end{array}$ & $\begin{array}{l}\text { AGFI value } \\
\text { closer to } 1= \\
\text { better }\end{array}$ & $\begin{array}{l}\text { AGFI } \geq 0.09 \\
=\text { better }\end{array}$ & 0.723 & Acceptable \\
\hline $\begin{array}{l}\text { TLI } \\
\text { (Tucker-Lewis } \\
\text { index) }\end{array}$ & $\begin{array}{l}\text { TLI value closer } \\
\text { to } 1=\text { better }\end{array}$ & $\begin{array}{l}\text { TLI } \geq 0.09= \\
\text { better }\end{array}$ & 0.696 & Acceptable \\
\hline $\begin{array}{l}\text { CFI } \\
\text { (comparative } \\
\text { fit index) }\end{array}$ & $\begin{array}{l}\text { CFI value closer } \\
\text { to } 1=\text { better }\end{array}$ & $\begin{array}{l}\text { CFI value } \\
\text { closer to } 1= \\
\text { better }\end{array}$ & 0.617 & Acceptable \\
\hline $\begin{array}{l}\text { NFI } \\
\text { (normal fit } \\
\text { index) }\end{array}$ & - & $\begin{array}{l}\text { NFI } \geq 0.09= \\
\text { better }\end{array}$ & 0.621 & Acceptable \\
\hline $\begin{array}{l}\text { PNFI } \\
\text { (parsimonious } \\
\text { fit index) }\end{array}$ & - & $\begin{array}{l}\text { Higher PNFI } \\
\text { value = } \\
\text { better }\end{array}$ & 0.583 & Acceptable \\
\hline $\begin{array}{l}\text { RMR } \\
\text { (root mean } \\
\text { squared } \\
\text { residual) }\end{array}$ & $\begin{array}{l}\mathrm{RMR} \leq 0.05= \\
\text { better }\end{array}$ & $\begin{array}{l}\mathrm{RMR} \leq 0.05 \\
=\text { better }\end{array}$ & 0.074 & Marginal \\
\hline Reliability & $\begin{array}{l}\text { Reliability } \geq 0.70 \\
=\text { better }\end{array}$ & $\begin{array}{l}\text { Reliability } \geq \\
0.70=\text { better }\end{array}$ & 0.773 & Acceptable \\
\hline
\end{tabular}

b. Source: (Anantadjaya, 2011; Indra \& Anantadjaya, 2011; Ghozali, 2004; Santoso, 2009; Schumacker \& Lomax, 2004; Mustafa \& Wijaya, 2012)

Consumer characteristics positively influence the formation of restaurant design as much as $61 \%$. Of the indicators used to approximate consumer characteristics, culture has the highest explanatory power of $76 \%$ toward the formation of consumer characteristics (Solomon, 2013). The explanatory powers of social and personal are $70 \%$ and $58 \%$ toward the formation of consumer characteristics (Kotler \& Keller, 2012; Solomon, 2013; Mullins \& Walker, 2010). This means that culture present the most influential impact toward what consumer characteristics (Shah, 2016) would become. Managers should consider the elements on cultural issues in the society to approximate the likelihood of tastes and preferences toward designs. As a close "relative", social issues also present a relatively influential impact. The combinations of the indicators have shown the empirical evidence that the consumer characteristics are shaped by the culture (Management Study Guide, 2016a), social and personal (Management Study Guide, 2016b) elements. This directs that depending on the respondents' culture, social and personal elements, the overall consumer characteristics may be different. On one side, these differences guide the consumer characteristics. On another side, such differences form the most preferred restaurant designs. For example, in most parts of Asian countries, people value family-close-ties. Children tend to stay together with parents even after marriages. These 
closely-tied family relationships would significantly impact the individual's sets of habits, beliefs and principles. This shapes the unique consumer characteristics based on what the localized culture (Management Study Guide, 2016a).

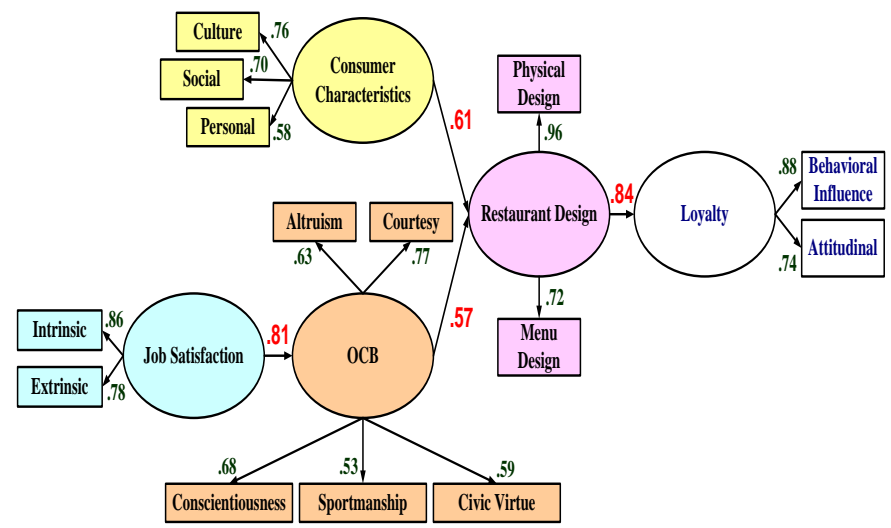

Fig. 2. Structural Equation Source: AMOS

OCB positively influences the formation of restaurant design as much as $57 \%$. Of the indicators used to approximate OCB, courtesy has the highest explanatory power of $77 \%$. At about the similar level of influences, altruism and conscientiousness have $63 \%$ and $68 \%$ explanatory power toward $\mathrm{OCB}$, respectively. This means that in trying to formulate the most appropriate restaurant design, courtesy among employees appears to be the upmost important. As courtesy refers to prior, early or immediate notices to colleagues upon managerial changes (Ünal, 2013), communication among team members should be considered crucial to ensure the restaurant design, perhaps, as well as the maintenance of such restaurant designs.

Restaurant design positively influences the formation of customer loyalty as much as $84 \%$. Of the indicators used to approximate restaurant design, physical design appears to be having the highest explanatory power of $96 \%$. Menu design poses a total explanatory power of $72 \%$. This means that the physical design of the restaurant present the most influential impact toward what people believe the restaurant design should be. This becomes understandable since the physical design of restaurants is likely directing the "theme" of restaurants. When restaurants can relay the message carefully with the physical designs, the level of satisfactions is influenced. Eventually, the level of satisfaction may likely contribute the level of loyalty over time. Referring to the indicators used to approximate loyalty, the behaviors portray the most influential explanatory power of $88 \%$. This means that to boost loyalty toward restaurants, management and owners of restaurants should focus on inspiring and altering the behaviors of patrons in such a way that those patrons' behaviors may be modified accordingly.

With the above results and with regards to the hypothesis in this study, the hypothesis tests can be addressed as showed at Tabel 4.

\section{CONCLUSION}

This study concludes that all of the variables used show positive influence toward the customer loyalty. All of the indicators also show satisfactory explanatory power toward the formation of the intended variables. With the results show the most contribution impact of intrinsic job satisfaction, culture, courtesy, physical design and behavioral influence, it is apparent that the ultimate goal is to strive for total positive customer experience.

With those results, it is obvious that management shall concentrate on those indicators toward improvements attempts in reaching the highest level of loyalty. At first, it becomes important to note the competing employees' interests based on intrinsic and extrinsic factors on job satisfaction. This means that not only organizations need to ensure the satisfactory conditions on the job, from supervisors, compensations, relationships among employees, but also the necessities on awards, recognitions, challenging jobs to push-forth employees' job satisfaction level. At the second layer, organizations need to distinguish the vital roles of courtesy among employees, conscientiousness and altruism toward the betterment of OCB. As the combination of courtesy and altruism forms the individual-based $\mathrm{OCB}$, it becomes crucial for organizations to ensure team-based organizational structure. This pushes employees to work together and may be demanded to constantly stay alert with problems and/or challenges faced by colleagues to reach the common goals and completions of tasks on-hand. Coupled with the high degree of conscientiousness, which represent the organizational-based OCB, outcomes may be guaranteed to be always in the best possible quality. At least, this pledges for continuous improvement among employees. To better comprehend the consumer characteristics, organizations need to emphasize on cultural elements. This means to really conduct demographical analysis to formulate the consumer profiles as a way to understand the consumer/market characteristics. This appears to be the most influential elements to better equipped organizations in deciding the most appropriate designs in restaurants. At least, from the physical appearances and ambience of the restaurants. Combining with the ultimate target on loyalty, successfully delivering the superb customer experience, or popularly known as experiential marketing, becomes the important managerial "threads" to focus on.

Future research can certainly focus on the similar variables and indicators with additional focus on cultural and social elements to note the possible differences across cultural groups and social groups. Detailing more on the level of personal diversity may pose exciting impact toward appropriate restaurant designs. 
TABLE IV HYPOTHESIS TESTS

\begin{tabular}{|c|c|c|c|c|}
\hline & & Hypothesis & Results & $\begin{array}{l}\text { Regression } \\
\text { Weight } \\
\text { (Maximum } \\
\text { Likelihood) }\end{array}$ \\
\hline $\mathrm{H}_{1}$ & : & $\begin{array}{l}\text { Consumer characteristics } \\
\text { positively influences } \\
\text { restaurant design }\end{array}$ & $\begin{array}{l}\mathrm{H}_{1} \text { is not } \\
\text { rejected }\end{array}$ & 0.61 \\
\hline $\mathrm{H}_{2}$ & : & $\begin{array}{l}\text { Job satisfaction positively } \\
\text { influences OCB }\end{array}$ & $\begin{array}{l}\mathrm{H}_{2} \text { is not } \\
\text { rejected }\end{array}$ & 0.81 \\
\hline $\mathrm{H}_{3}$ & : & $\begin{array}{l}\text { OCB positively influences } \\
\text { restaurant design }\end{array}$ & $\begin{array}{l}\mathrm{H}_{3} \text { is not } \\
\text { rejected }\end{array}$ & 0.57 \\
\hline $\mathrm{H}_{4}$ & : & $\begin{array}{ll}\text { The appropriate } & \text { restaurant } \\
\text { design } & \text { positively } \\
\text { influences } & \text { customer } \\
\text { loyalty } & \\
\end{array}$ & $\begin{array}{l}\mathrm{H}_{4} \quad \text { is not } \\
\text { rejected }\end{array}$ & 0.84 \\
\hline
\end{tabular}

c. Source: (IBM SPSS Amos, 2016)

\section{REFERENCES}

Alsaqre, O. Z. (2011, April). Investigating the Effects of Tangible and Intangible Factors on Customers' Perceived Service Quality and Loyalty in Hotel Industry in Al-Ladhiqiyah, Syria. Retrieved July 4, 2015, from United Nation World Tourism Organization:

http://cf.cdn.unwto.org/sites/all/files/alsaqre_research.p df

Anantadjaya, S. P. (2011, March). Kualitas Sumber Daya Manusia dan Group Synergy Sebagai Faktor Pencipta Kinerja Organisasi pada Perusahaan Terbuka yang Tercatat di Bursa Efek Indonesia. Doctoral Dissertation, NPM \#2006-81-2001, Program Doktor Ilmu Ekonomi . (H. Djajadikerta, P. Sukapto, A. Widjana, W. Bangun, \& M. Susan, Eds.) Bandung, Jawa Barat, Indonesia: Universitas Katolik Parahyangan.

Arbuckle, J. L. (2011). IBM SPSS AMOS 20 User's Guide. New York: IBM Corporation.

Arif, A., \& Chohan, A. (2012). How Job Satisfaction is Influending the Organizational Citizenship Behavior (OCB): A Study on Employees Working in Banking Sector of Pakistan. Interdisciplinary Journal of Contemporary Research in Business , 4 (8), 74-88.

Ariffin, H. F., Bibon, M. F., \& Saadiah, R. P. (2011). Restaurant's Atmospheric Elements: What the Customer Wants. Journal of ASIAN Behavioural Studies , 1 (2), 34-36.

Arokiasamy, A. R., Tat, H. H., \& Abdullah, A. G. (2013). The Effects of Reward System and Motivation on Job Satisfaction: Evidence from the Education Industry in Malaysia. World Applied Sciences Journal , 24 (12), 1597-1604.

Aworemi, J., Abdul-Azeez, I., \& Durowoju, S. (2011). An Empirical Study of the Motivational Factors of Employees in Nigeria . International Journal of Economics and Finance, 227- 233

Aziri, B. (2011). Job Satisfaction: A Literature Review. Management Research and Practice , 3 (4), 77-86.
Baiomy, A. E., Jones, E., Elias, A. N.-D., \& Dinana, R. T. (2013). Menu as Marketing Tools: Developing a Resort Hotel Restaurant Menu Typology. Journal of Tourism Research \& Hospitality , 2 (2), 1-10.

Baylor, K. M. (2010). The Influence of Intrinsic and Extrinsic Job Satisfaction Factors and Affective Commitment on the Intention to Quit for Occupations Characterized by High Voluntary Attrition. Dissertation, Publication \# 3404479, School of Business \& Entrepreneurship . (F. B. Barnes, R. A. Greenwood, T. E. Griffin, S. Weisfeld-Spolter, \& J. P. Jones, Eds.) Fort Lauderdale, FL, USA: Nova Southeastern University.

Bowen, J. T., \& Morris, A. J. (1995). Menu Design: Can Menus Sell. International Journal of Contemporary Hospitality Management , 7 (4), 4-9.

Bradler, C., Dur, R., Neckermann, S., \& Non, A. (2016, February 9). Employee Recognition and Performance: A Field Experiment. Management Science

Buchanan, N. (2011, November 15). An Examination of Electronic Tablet-Based Menus for the Restaurant Industry. Graduate Thesis, Master of Science Program, Department of Hotel, Restaurant and Institutional Management . (S. Beldona, Ed.) Newark, DE, USA: University of Delaware.

Chartrand, J. (2010, August 27). 7 Secrets Graphic Designers Won't Tell You about Effective Website Design. Retrieved September 20, 2014, from KISSmetrics, San Francisco: https://blog.kissmetrics.com/graphicdesigner-secrets/

Cooper, D. R., \& Schindler, P. S. (2011). Business Research Methods. New York City, NY, USA: McGrawHill Companies.

Craven, D. W., \& Piercy, N. F. (2009). Strategic Marketing (9th ed.). New York City, NY, USA: McGraw-Hill Education.

Davoudi, S. M. (2012). A Comprehensive Study of Organizational Citizenship Behavior (OCB): Introducing the Term, Clarifying Its Consequences and Identifying Its Antecedents. Arth Prabhand: A Journal of Economics and Managem ent , 73-85.

Ebert, R. J., \& Griffin, R. W. (2011). Business Essentials. Upper Saddle River, NJ, USA: Prentice Hall/Pearson Education, Inc.

Ehsan, M. M., Ali, Q., Hunbal, H., Noman, M., Ahmad, B., \& Muhammad, I. H. (2013). Impact of Brand Image and Advertisement on Consumer Buying Behavior. World Applied Science Journal , 117-122.

Eliwa, R. A. (2006). A Study Of Customer Loyalty And The Image of The Fine Dining. Graduate Thesis, Master of Science in Marketing, Oklahoma State University, ID \# 1440401 . (H. Qu, Ed.) Stillwater, OK, USA: Oklahoma State University.

Ertzberger, B. K. (2009). The Effect of Ambient Factors in the Design and Branding of the Restaurant Environment: A 
Business Approach Model Exemplified in "Café Cabernet", Tallahassee, Florida. Graduate Thesis, Department of Interior Design , 11-26. (P. Munton, J. Pable, \& K. Myers, Eds.) Tallahassee, FL, USA: Florida State University.

Ghozali, I. (2011). Aplikasi Analisis Multivariate dengan Program IBM SPSS 20. Semarang: Badan Penerbit Universitas Diponegoro.

Ghozali, I. (2004). Model Persamaan Struktural: Konsep dan Aplikasi dengan Program AMOS ver. 5.0. Semarang, Indonesia: Badan Penerbit Universitas Diponegoro.

Holscher, D. (2013, August 30). Restaurant Loyalty Programs Pay-Off in Surprising Ways. (Networld Media Group, LLC) Retrieved March 14, 2014, from FastCasual: http://www.fastcasual.com/blog/11055/

Honigman, B. (2013, March 26). Psychology of Color in Logo Design (INFOGRAPHIC), p. Business.

Houser, J. (2011). Nursing Research: Reading, Using, and Creating Evidence (2nd ed.). Sudbury, MA, USA: Jones and Bartlett Publishers.

Hung, L. M. (2012). A Study of Consuming Behavior in Budget Coffee. Business and Management Research , 48-61.

Hussin, A. B. (2011, October). The Relationship Between Job Satisfaction and Job Performance Among Employees in Tradewinds Groups of Companies. (S. Samad, Ed.) Retrieved March 1, 2014, from Graduate Thesis, Centre for Graduate Studies, Master of Human Resources Management: http://library.oum.edu.my/repository/668/1/relationship _anuar.pdf

IBM SPSS Amos. (2016, May 20). Structural Equation Modeling. Maximum Likelihood Estimates . (S. P. Anantadjaya, I. M. Nawangwulan, \& A. P. Nova, Compilers) Bandung, Jawa Barat, Indonesia: IBM.

Indra, J., \& Anantadjaya, S. P. (2011). Balancing the Firm's Scores: A Performance and Control Study in Indonesian Financing Industry. 7th Asia Pacific Management Accounting Association Conference \& Doctoral Colloquium Proceedings (pp. 1-27). Shah Alam, Malaysia: APMAA: Asia Pacific Management Accounting Association.

Ishak, M. S., Ahmad, M., Rahman, M. N., \& Rofie, M. K. (March 4-5, 2013). Predicting Intentions to Visit KopiTiams as Halal Food Outlet: An Extension of the Theory of Planned Behavior. 4th International Conference on Business and Economic Research (4th ICBER 2013). Bandung: International Conference Malaysia.

Islam, T., Ahmad, Z., Ahmed, I., \& Mohammad, S. K. (2012). Key Factors of Organizational Citizenship Behavior in The Banking Sector of Pakistan. African Journal of Business Management, 3296-3302.

James, J., \& Baldwin, D. (2003). Streetwise Restaurant Management: A Comprehensive Guide to Successfully
Owning and Running a Restaurant. Avon, MA, USA: Adams Media, F+W Publication, Inc.

Kaifi, B. A., \& Noori, S. A. (2011). Organizational Behavior: A Study on Managers, Employees, and Teams. Journal of Management Policy and Practice , 88-97.

Kernodle, T., \& Noble, D. (2013). Organizational Citizenship Behavior: It's Importance In Academics. American Journal Of Business Education , 235-240.

Khan, S., Hussein, S. M., \& Yaqoob, F. (2012). Determinants of Customer Satisfaction in Fast Food Industry. Journal of Management and Strategy , 1-15.

Kotler, P., \& Armstrong, G. (2014). Principles of Marketing (15th/Global ed.). (S. Wall, Ed.) Essex, UK: Pearson Education Limited.

Kotler, P., \& Keller, K. L. (2012). Marketing Management (14th ed.). Harlow, UK: Pearson Education Limited.

Kotschevar, L. H., \& Withrow, D. (2008). Management by Menu (4th ed.). Hoboken, NJ, USA: John Wiley \& Sons, Inc.

Kumari, N. (2011). Job Satisfaction of the Employees at the Workplace. European Journal of Business and Management , 11-30.

Kurtus, R. (2008, January 12). Restaurant Quality. Retrieved June 6, 2014, from TQM: http://www.school-forchampions.com/tqm/restaurant_quality.htm\#.U51JFPm Syuo

Kurtz, D. L., \& Boone, L. E. (2006). Principles of Marketing. Mason, OH, USA: South-Western.

Lantos, G. P. (2011). Consumer Behavior in Action: Real Life Applications for Marketing Managers. New York City, NY, USA: ME Sharpe.inc.

Leblebici, D. (2012). Impact of Workplace Quality on Employee's Productivity: Case Study of a Bank in Turkey. Journal of Business, Economics \& Finance , 1 (1), 38-49.

Malekshahi, A. (2013, February). Investigation on Restaurant Layout Design. Graduate Thesis, Master of Science in Architecture . (E. Yilmaz, Ö. Dinçyürek, N. Özay, K. Öztürk, \& C. Boğaç, Eds.) Gazimağusa, Cyprus: Eastern Mediterranean University.

Malik, M. E., Ghafoor, M. M., Iqbal, H. K., Ali, Q., Hunbal, H., Noman, M., et al. (2013). Impact of Brand Image and Advertisement on Consumer Buying Behavior. World Applied Sciences Journal , 117-122.

Management Study Guide. (2016a). Cultural Factors affecting Consumer Behaviour. Retrieved November 4, 2016, from Courses - Marketing - Consumer Behaviour: http://www.managementstudyguide.com/culturalfactors-affecting-consumer-behaviour.htm

Management Study Guide. (2013). Herzberg's Two-Factor Theory of Motivation. Retrieved April 1, 2014, from Organizational Behavior - Motivation: http://managementstudyguide.com/herzbergs-theorymotivation.htm 
Management Study Guide. (2016b). Personal Factors affecting Consumer Behaviour. Retrieved November 4, 2016, from Home - Marketing - Consumer Behaviour: http://www.managementstudyguide.com/personalfactors-affecting-consumer-behaviour.htm

Manzoor, Q. A. (2012). Impact of Employees Motivation on Organizational Effectiveness. Macrothink Institute Business Management and Strategy , 1-12.

Marković, S., Raspor, S., \& Šegarić, K. (2010). Does Restaurant Performance Meet Customer Expectation? An Assessment of Restaurant Service Quality Using a Modified Dineserv Approach. Tourism \& Hospitality Management , 16 (2), 181-195.

Miao, R. T. (2011). Perceived Organizational Support, Job Satisfaction, Task Performance and Organizational Citizenship Behavior in China. Institute of Behavioral and Applied Management, 105-127.

Micro Format, Inc. (2014). Paper Weight \& Size. Retrieved April 28, 2014, from Let's End the Confusion: http://www.paper-paper.com/weight.html

Mohammad, J., Habib, F. Q., \& Alias, M. A. (2011). Job Satisfaction and Organizational Citisenship Behaviour: An Empirical Study at Higher Learning Institutions. Asian Academy of Management Journal , 149-165.

Mullins, J. W., \& Walker, O. C. (2010). Marketing Management: A Strategic Decision-Making Approach (8th ed.). New York City, NY, USA: McGraw-Hill Companies, Inc.

Mustafa, Z., \& Wijaya, T. (2012). Panduan Teknik Statistik SEM \& PLS dengan SPSS AMOS. Yogyakarta, DI Yogyakarta, Indonesia: Cahaya Atma Pusaka.

Nadim, M., Chaudhry, M. S., Kalyar, M. N., \& Riaz, T. (2012). Effects of Motivational Factors on Teachers' Job Satisfaction: A Study on Public Sector Degree Colleges of Punjab, Pakistan. The Journal of Commerce , 4 (4), 25-32.

Narayan, R. (2010). Human Resource Accounting: A New Paradigm in the Era of G lobalization. Asian Journal of Management Research , 237-244.

National Restaurant Association. (2013a, May 23). 2013 National Restaurant Association Restaurant, HotelMotel Show Sees Strong Post-Recession Gain in Attendee and Exhibitor Numbers. (National Restaurant Association, Washington, DC, USA) Retrieved March 01, 2014, from Press Releases: http://www.restaurant.org/Pressroom/PressReleases/2013-National-Restaurant-AssociationRestaurant,-H

National Restaurant Association. (2013b). Marking Mark Through Your Menu Design. (National Restaurant Associations, Washington DC, USA) Retrieved March 26, 2015, from Manage My Restaurant - Marketing Sales - In-Store Experience: http://www.restaurant.org/Manage-My-
Restaurant/Marketing-Sales/Promotion/Making-yourmark-through-menu-design

Newland, S. J. (2012, May). Organizational Citizenship Behavior-Individual or Organizational Citizenship Behavior-Organization: Does the Underlying Motive Matter? Graduate Thesis, Master of Arts, Department of Psychology, Paper ID \# 1159 . (E. Shoenfelt, R. Brown, \& A. Wichman, Eds.) Bowling Green, KY, USA: Western Kentucky University.

Ozdemir, B., \& Caliskan, O. (2013). A Review of Literature on Restaurant Menus: Specifying the Managerial Issues. International Journal of Gastronomy and Food Science , 2 (1), 3-13.

Öztürk, F. (2010, August). Determinants of Organizational Citizenship Behavior Among Knowledge Workers: The Role of Job Characteristics, Job Satisfaction, and Organizational Commitment. Graduate Thesis, Master of Business Administration . (F. P. Acar, Ed.) Ankara, Turkey: Middle East Technical University.

Parsa, H. G., Gregory, A., Self, J. T., \& Dutta, K. (2012). Consumer Behavior in Restaurants: Assessing the Importance of Restaurant Attributes in Consumer Patronage and Willingness to Pay. Journal of Services Research , 12 (2).

Pavesic, D. V. (2005, February). The Psychology of Menu Design: Reinvent Your 'Silent Salesperson' to Increase Check Averages and Guest Loyalty. Hospitality Faculty Publication \# 2-2005, Cecil B Day School of Hospitality Administration , 37-43. Atlanta, GA, USA: Georgia State University.

Pennisi, L. A., \& Winder, A. A. (2011). Effective Graphic Design. Extension Publication, G-2031.

PHStat. (2016, March 1). Sample Size. Microsoft Excel AddIns . (S. P. Anantadjaya, Compiler) BSD City, Serpong, Tangerang, Banten, Indonesia.

Putra, A. N., Saroso, P. A., \& Anantadjaya, S. P. (2015). Physical Menu Design: One Important Marketing Tool. Saarbrucken, Germany: Lambert Academic Publishing.

Reid, R. D., \& Bojanic, D. C. (2009). Hospitality Marketing Management (5th ed.). Upper Sadle River, NJ, USA: John Wiley \& Sons, Inc.

Robbins, S., \& Judge, T. (2013). Organizational Behavior. New Jersey: Pearson Education, Inc.

Robson, S. (2002, December). Strategies for Designing Effective Restaurants. Retrieved October 28, 2016, from Implications: http://www.informedesign.org/_news/dec_v02-p.pdf

Saepung, W., Sukirno, \& Siengthai, S. (2011). The Relationship between Job Satisfaction and Organizational Citizenship Behavior (OCB) in the Retail Industry in Indonesia. World Review of Business Research , 162-178.

Sageer, A., Rafat, D. S., \& Agarwal, P. (2012). Identification of Variables Affecting Employee Satisfaction and 
Their Impact on the Organization. IOSR Journal of Business and Management , 32-39.

Santoso, S. (2009). SEM, Konsep dan Aplikasinya pada AMOS. Jakarta, Indonesia: PT. Elex Media Komputindo.

Sarwono, J. (2012). Metode Riset Skripsi. Jakarta: PT. Elex Media Komputindo.

Scanlon, N. L. (1985). Marketing by Menu: A Total Concept. Boston, MA, USA: Van Nostran Reinhold Company/CBI Publishing.

Schiffman, L., \& Kanuk, L. (2009). Consumer Behavior (10th ed.). New York City, NY, USA: Prentice Hall.

Schumacker, R. E., \& Lomax, R. G. (2004). A Beginner's Guide to Structural Equation Modelling (Vol. 2nd Edition). New Jersey, USA: Lawrence Erlbaum Associates, Inc. Publishers.

Setiawan, F. (2011, July). Analysis of Consumer Behavior in Small Food Retailers: Empirical Study in BSD City. Undergraduate Thesis, School of Hotel \& Tourism Management, Faculty of Business Administration \& Humanities . (S. P. Anantadjaya, Ed.) BSD, Tangerang, Indonesia: Swiss German University.

Shah, A. (2016). Factors Affecting Consumer Behavior. (Association of International Product Marketing \& Management (AIPMM)) Retrieved November 4, 2016, from

Newsletter: http://www.aipmm.com/html/newsletter/archives/0004 34.php

Shock, P. J., Bowen, J. T., \& Stefaneli, J. M. (2004). Restaurant Marketing for Owner and Managers. Hoboken, NJ, USA: John Wiley \& Sons, Inc.

Simpson, R. J. (2003, December). Theme and Experience in Restaurant Design: A Theory. (C. Bicknell, M. Melcher, \& D. Wang, Eds.) Retrieved April 1, 2014, from Dissertation, Department of Apparel, Merchandising and Interior Design, Master of Art, Washington State University: http://www.dissertations.wsu.edu/Thesis/Fall2003/r_si mpson_091203.pdf

Singh, S. (2006). Impact of Color on Marketing. Management Decision , 44 (6), 783-789.

Solomon, M. R. (2013). Consumer Behavior: Buying, Having, and Being (10th ed.). Harlow, UK: Pearson Education Limited.

StuCo, Ltd. (2012, August 27). Printing Terms: What Does GSM Mean? Which GSM or Paperweight is Right for Me? Retrieved April 28, 2014, from Latest News \& Offers: https://www.stuprint.com/news/what-does-gsmmeans

Suma, S., \& Lesha, J. (2013). Job Satisfaction and Organizational Commitment: The Case of Shkodra Municipality. European Scientific Journal , 41-51.
Tanaka, K. (2013). Oganizational Citizenship Behavior in Contemporary Workplaces in Japan. Japan Labor Review , 5-18.

Thenni, E. (2013). The Analysis of Important Elements in Creating Great Atmosphere in 5 Star Hotels. Undergraduate Thesis, ID \# 1-3309-037, School of Hotel \& Tourism Management, Faculty of Business Administration \& Humanities . (P. A. Saroso, Ed.) BSD City, Serpong, Tangerang, Indonesia: Swiss German University.

Ünal, Ö. F. (2013). Relationship Between the Dimensions of Organizational Citizenship Behavior and the Facets of Job Satisfaction (An Empirical Study in a Group of Companies in Turkey). WEI International Academic Conference Proceedings (pp. 123-137). Antaly, Turkey: The West East Institute.

Vaijayanthi, P., Shreenivasan, K., \& Roy, R. (2014). Deducting the Organizational Citizenship Behavior Dimensions and its Antecedents (Job Satisfaction) in the Indian Context. Research Journal of Applied Sciences, Engineering and Technology , 1953-1960.

Wijaya, T. (2009). Analisis Structural Equation Modeling Menggunakan AMOS. Yogyakarta, Indonesia: Universitas Katolik Atmajaya.

Yu, X. (2009). Sensory Study in Restaurant Interior Design. Retrieved April 1, 2014, from Graduate Thesis, Master of Arts. Paper 11104, School of Art and Design (Interior Design), Iowa State University, Ames, Iowa, USA: http://lib.dr.iastate.edu/cgi/viewcontent.cgi?article=215 $1 \&$ context=etd 